\title{
Perkembangan Kognitif Anak Selama Belajar Di Rumah
}

\author{
Veny lswantiningtyas \\ PG-PAUD-FKIP \\ Universitas Nusantara PGRI Kediri \\ veny@unpkediri.ac.id
}

\begin{abstract}
Early childhood education has had a bad impact due to the Covid-19 pandemic. The government took a policy to conduct distance learning activities. In order for early childhood to retain their rights in the form of education, teachers and parents use a home learning approach. Parents play an important role in education as long as children learn at home, for example, to develop children's cognitive. One of the factors that influence cognitive development is the school environment. During this pandemic, almost all schools carry out teaching and learning activities using an online system, so that more or less it will affect the achievement of children's cognitive development. The purpose of this research was to determine the achievement of early childhood cognitive development during home study. This research is qualitative research with the subject of group B children at TK Kusuma Mulia Sidomulyo I Puncu Kediri, were in data collection using a cognitive development achievement assessment sheet involving teachers, the main reason researchers chose teachers was because researchers could not directly observe children about developmental achievements. cognitive. The filling out of the assessment sheet for the achievement of cognitive development carried out by the teacher based on the data obtained for 1 semester, the results of the study prove that during learning at home the achievement of children's cognitive development is still achieved.
\end{abstract}

Keywords: Children's Cognitive Development Achievements, Learning at Home

\begin{abstract}
Abstrak
Pendidikan anak usia dini merasakan dampak buruk akibat adanya pandemi covid-19. Pemerintah mengambil kebijakan untuk melakukan kegiatan pembelajaran jarak jauh. Agar anak usia dini tetap mendapatkan haknya berupa pendidikan, guru dan orang tua menggunakan pendekatan belajar di rumah. Selama kegiatan belajar di rumah guru dan orang tua mempunyai tantangan yang harus di hadapi. Orang tua memegang peran penting akan pendidikan selama anak belajar di rumah, misalnya untuk mengembangkan kognitif anak. Salah satu faktor yang mempengaruhi perkembangan kognitif adalah lingkungan sekolah. Dimasa pandemi ini, hampir seluruh sekolah melakukan kegiatan belajar mengajar menggunakan sistem daring, sehingga sedikit banyak akan dapat mempengaruhi capaian perkembangan kognitif anak. Tujuan dilakukan penelitian untuk mengetahui capaian perkembangan kognitif anak usia dini selama belajar dirumah. Penelitian ini merupakan penelitian kualitatif dengan subyek anak kelompok B TK Kusuma Mulia Sidomulyo I Puncu kediri, dimana dalam penggumpulan data menggunakan lembar penilaian capaian perkembangan kognitif dengan melibatkan guru, alasan utama peneliti memilih guru karena peneliti tidak dapat melakukan pengamatan secara langsung kepada anak tentang capaian perkembangan kognitif. Pengisian lembar penilaian capaian perkembangan kognitif yang dilakukan oleh guru berdasarkan data yang diperoleh selama 1 semester, hasil penelitian membuktikan bahwa selama belajar di rumah capaian perkembangan kognitif anak tetap tercapai.
\end{abstract}

Kata Kunci : Capaian Perkembangan Kognitif Anak, Belajar di Rumah

\section{PENDAHULUAN}

Perkembangan kognitif merupakan salah satu perkembangan yang dimiliki oleh anak. Pengembangan kognitif termasuk dalam aspek pengembangan yang perlu distimulasi ketika kegiatan belajar mengajar dilakukan di lembaga PAUD. Perkembangan kognitif erat kaitannya dengan cara berpikir seseorang yang mengambarkan aktivitas intelektual, pada anak aktivitas tersebut akan tampak saat mengetahui, memahami, mengingat sesuatu. Menurut Vygotsky (dalam Suwardi dan Daryanto, 2017) perkembangan kognitif seoseorang selain ditentukan oleh individu sendiri juga dipengaruhi oleh 


\section{Efektor, Volume 8 Issue 1, 2021, Pages 9 - 20}

Veny Iswantiningtyas

lingkungan sosial. Selain itu, Patmonodewo (2008) mengemukakan perkembangan kognitif menunjukkan terjadinya perubahan tentang cara berpikir anak. Kemampuan anak untuk menyelaraskan cara berpikirnya agar ia mampu menyelesaikan masalah merupakan tolak ukur dari perkembangan kognitifnya. Sedangkan menurut Bruner (dalam Jamaris, 2013) menjelaskan perkembangan kognitif merupakan suatu perkembangan kemampuan berpikir yang berkembang secara bertahap. Dalam Peraturan Menteri Pendidikan dan Kebudayaan Republik Indonesia Nomor 137 Tahun 2014 tentang Standar Nasional Pendidikan Anak Usia Dini dalam Standar Isi Tentang Tingkat Pencapaian Perkembangan Kognitif anak distimulasi sesuai dengan usianya, lingkup perkembangan kognitif dibagi menjadi 3 bagian, yaitu: 1) belajar dan pemecahan masalah, 2) berfikir logis dan 3) berfikir simbolik.

Kognitif anak harus dikembangkan sejak ia berusia dini, agar ia dapat mengetahui berbagai macam simbol yang terdapat disekitarnya, anak akan berusaha memecahkan masalah yang lebih mudah yang terjadi di kehidupannya sehingga nantinya ia mampu menjelma menjadi pribadi yang dapat menolong dirinya, melatih ingatanya tentang berbagai kejadian yang telah dialaminya, mengembangkan penalarannya untuk menghubungkan peristiwa satu dengan peristiswa lainnya. Sejalan dengan pengkajian Setyaningrum et al (2014) mengemukakan faktor dominan yang berkaitan tentang perkembangan kognitif ialah kegiatan pembelajaran yang dilakukan di PAUD, anak yang telah mengikuti pembelajaran di PAUD memiliki kesempatan kognitifnya berkembang empat kali lipat dibandingkan anak yang tidak mengikuti. Penelitian sejenis juga pernah dilakukan oleh (Tatminingsih, 2019) bahwa seluruh lembaga PAUD yang ada di negara Indonesia mempraktekkan pembelajaran stimumulasi yang banyak pada kegiatan belajar mengajar kognitif. Hal tersebut terjadi karena kebanyakan orang tua yang beranggapan bahwa anak yang memiliki kemampuan kognitif yang tinggi dianggap sebagai anak yang cerdas yang akan berhasil pada kehidupannya kelak.

Munculnya covid-19 juga menimbulkan berbagai permasalahan pada bidang pendidikan yaitu beralihnya kegiatan belajar dari tatap muka menjadi daring secara jarak jauh, hal ini disesuaikan dengan Surat Edaran Menteri Pendidikan dan Kebudayaan No.4 Tahun 2020 tentang pelaksanaan proses pembelajaran jarak jauh menggunakan sistem pembelajaran daring. Pembelajaran yang diterapkan pada anak berusia dini dilakukan di rumah selama adanya covid-19. Hal tersebut dilakukan, karena anak merupakan seseorang yang labil dan senang berkumpul dengan temannya sehingga memungkinkan untuk terjadinya penyebaran virus. Pendidikan anak usia dini menitik beratkan adanya hubungan antara guru dengan peserta didik yang berupaya membantu peserta didik dalam mencapai seluruh aspek perkembangannya. Selama ada pandemi covid-19 seluruh pihak yakni guru, murid serta orang tua melakukan kehidupan baru / new normal menggunakan pendekatan belajar di rumah. Orang tua mempunyai kewajiban terhadap pendidikan anak selama belajar di rumah, misalnya untuk mengembangkan kognitif anak. Orang tua dapat menstimulasi perkembangan kognitif dengan berbagai cara seperti : belajar berhitung, mengenal bentuk, melakukan eksperimen sederhana serta aneka cara dapat dilakukan untuk menstimulasi perkembangan kognitif anak.

Pola pembelajaran pada anak di usia dini didasari dengan pengembangan kurikulum secara nyata yang berisi program pembelajaran melalui bermain dan dilakukan dengan keterlibatan aktif oleh guru dan anak. Karena adanya pandemi Covid-19 segala aktifitas bermain sambil belajar anak dibantu oleh orang tua, dan semua aktivitas anak dilakukan di rumah bersama orang tua. Wardani \& Ayriza, (2020) mengungkapkan fakta ditemukan bermacam-macam kendala yang di hadapi oleh orang tua ketika menemani anaknya belajar di masa pandemi covid-19 adalah 1) orang tua kurang memahami materi pelajaran, 2) orang tua kesulitan bila meningkatkan minat belajar anak, 3) orang tua kurang 
mempunyai waktu yang cukup ketika menemani anak belajar karena musti bekerja, 4) keterbatasan kesabaran orang tua saat menemani anaknya belajar dirumah, 5) orang tua kesusahan apabila mengaplikasikan gadget, 6) ganguan jangkauan internet. Selain itu, Astuti \& Harun (2020) mengungkapkan fakta sewaktu belajar dirumah baik guru maupun orang tua menghadapi sejumlah tantangan adalah 1) guru terlebih dulu harus merancang kegiatan belajar yang menyenangkan serta menyesuaikan bahan yang ada dilingkungan sekeliling anak, 2) siap mengontrol semua aktivitas yang telah dilakukan anak lewat whatshapp dan home visit serta membuat penilaian. Sedangkan orang tua harus 1) mengendalikan mood belajar anaknya, mengajak anaknya untuk belajar dengan suasana yang menggembirakan, dan memilah waktunya mendampingi anak belajar dan melakukan pekerjaan.

Hasil penelitian yang telah dilakukan oleh Mutmainnah (2020) untuk melatih perkembangan kognitif anak dengan lingkup kemampuan critical thinking selama pembelajaran daring, rencana yang akan dilakukan oleh guru yakni melibatkan orang tua. Guru memiliki tugas membuat rencana pembelajaran harian dan melakukan penilaian berdasarkan hasil kegiatan yang telah dilaporkan orang tua, sedangkan orang tua berperan sebagai pendamping anak belajar dengan menggunakan metode percakapan dan tanya jawab. Selain itu, Iswantiningtyas (2020) menjelaskan bahwa strategi yang dilakukan oleh guru dalam mengembangkan perkembangan kognitif anak pada indikator keterampilan anak memecahkan masalah saat belajar di rumah pada anak adalah melakukan perubahan tugas pendidik anak disekolah (guru) yakni membuat perencanaan serta penilaian, sedangkan pendidik anak dirumah (orang tua) bertugas untuk melaksanakan kegiatan belajar di rumah pada anak. Menurut Pramana (2020), mengemukakan pendapatnya bahwa banyak tantangan serta hambatan ketika melaksankan pembelajaran dirumah yang dialami oleh lembaga pendidikan yaitu guru, anak dan orang tua dari segi prosedur pembelajaran, cara belajar dan respon anak pada objek pelajaran serta psikologis. Wulandari \& Purwanta (2020) pembelajaran daring dapat mempengaruhi capaian perkembangan anak, sebagian besar perkembangan anak mengalami penurunan kecuali seni. Penurunan paling besar terlihat pada aspek sosial emosional pada lingkup perilaku prososial.

Adanya kebijakan belajar di rumah mengakibatkan adanya perubahan kegiatan pembelajaran dilakukan di satuan pendidikan anak usia dini, kondisi demikian juga dapat berpengaruh pada capaian perkembangan anak. Tujuan penelitian yakni memberikan gambaran capaian perkembangan kognitif anak sewaktu belajar dirumah, kegiatan belajar yang dilakukan di rumah dapat memberikan pengetahuan yang berguna bagi anak. selain itu, selama anak belajar di rumah anak tidak terbebani oleh ketuntasan capaian kurikulum.

\section{METODE PENELITIAN}

Pendekatan yang digunakan adakah kualitatif, menggunakan teknik sampel jenuh yaitu 31 anak kelompok B TK Kusuma Mulia Sidomulyo I Puncu Kediri. Pengumpulan data menggunakan lembar penilaian perkembangan tertutup, cara menjawab pertanyaanya dengan cara memilih jawaban yang sudah tersedia di setiap pertannyannya. Guru diperbolehkan memilih jawaban yang sudah tersedia di setiap pertanyaan capaian perkembangan kognitif. Pengisian lembar penilaian capaian perkembangan kognitif dilakukan oleh guru berdasarkan penilaian akhir semester, alasan memilih guru sebagai pengisi atau penilai adalah peneliti tidak dapat secara langsung melakukan pengamatan pada anak tentang capaian perkembangan kognitif. Sejak satu tahun mengalami pandemi covid-19 TK Kusuma Mulia Sidomulyo I Puncu Kediri melakukan pembelajaran secara daring dari rumah masing-masing. Sebelum lembar penilaian capaian perkembangan kognitif diberikan terlebih dahulu peneliti memohon ijin kepada kepala sekolah serta menjelaskan tujuan dilakukannya penelitian. Lebih lanjut peneliti menjelaskan 


\section{Efektor, Volume 8 Issue 1, 2021, Pages 9 - 20}

Veny Iswantiningtyas

kepada guru tentang cara menjawab pertanyaan yaitu : terlebih dahulu guru melihat secara umum tentang semua catatan penilaian capaian perkembangan kognitif selama pembelajaran disekolah bertatap muka dan membandingkan pembelajaran dirumah. Hal tersebut dilakukan untuk melihat segala sesuatu yang berkaitan dengan pembelajaran dirumah tentang pencapaian perkembangan kognitif tercapai atau tidak. Data perolehan kemudian di analisis, dimana alur penelitiannya :

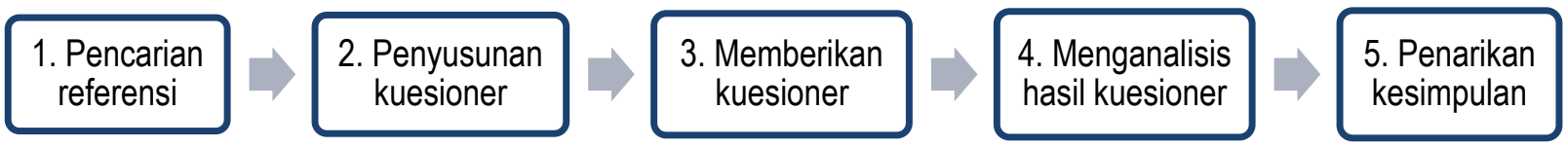

\section{Gambar 1. Bagan Alur Penelitian}

Dodge et al (2001) menyatakan bahwa perkembangan kognitif meliputi beberapa kemampuan yaitu: 1) to acquire learning dan problem solving skills; 2) to expand logical thinking skills; 3) to acquire concepts and information leading to a fuller understanding of the immediate world; 4) to demonstrate skills in make believe play; 5) to expand verbal communication skills; 6) to develop beginning reading skills; and 7) to acquire beginning reading skills. Sedangkan untuk mengetahui capaian perkembangan kognitif anak selama belajar dirumah, peneliti berpedoman pada Standart Tingkat Capaian Perkembangan Anak / STPPA mencakup: 1) Belajar memecahkan kesulitan, meliputi kecakapan mengatasi masalah yang mudah sesuai kehidupan anak secara luwes, diterima masyarakat dan mempergunakan pengetahuan baru; 2) berpikir rasional, meliputi beragam perbedaan, klasifikasi; 3) berpikir simbolik, meliputi kecakapan mengetahui, mengatakan, menggunakan konsep angka, huruf, serta mampu mencitrakan beraneka ragam benda dalam wujud gambar (Permendikbud No. 137 tahun 2014).

Tabel 1. Lembar Penilaian Capaian Perkembangan Kognitif Anak.

\begin{tabular}{|c|c|c|}
\hline No & Aspek & Capaian Perkembangan \\
\hline 1 & $\begin{array}{l}\text { Belajar dan } \\
\text { memecahkan } \\
\text { masalah }\end{array}$ & $\begin{array}{l}\text { Anak dapat memecahkan masalah sederhana dalam kehidupan } \\
\text { sehari-hari dengan cara yang fleksibel dan diterima sosial. } \\
\text { Anak mampu menerapkan pengetahuan / pengalaman dalam konteks } \\
\text { yang baru. } \\
\text { Anak dapat menunjukkan sikap kreatif dalam menyelesaikan masalah } \\
\text { (ide, gagasan di luar kebiasaan). }\end{array}$ \\
\hline 2 & Berpikir logis & $\begin{array}{l}\text { Anak mampu mengenal perbedaan berdasarkan ukuran : lebih dari, } \\
\text { kurang dari } \\
\text { Anak dapat mengenal pola ABCD } \\
\text { Anak mampu mengurutkan benda berdasarkan ukuran dari paling } \\
\text { kecil ke paling besar atau sebaliknya }\end{array}$ \\
\hline 3 & Berpikir simbolik & $\begin{array}{l}\text { Anak dapat menyebutkan lambang bilangan } 1-10 \\
\text { Anak mampu mencocokkan bilangan dengan lambang bilangan } \\
\text { Anak dapat Merepresentasikan berbagai macam benda dalam bentuk } \\
\text { gambar atau tulisan (ada benda pensil yang diikuti tulisan dan gambar } \\
\text { pensil) }\end{array}$ \\
\hline
\end{tabular}

Penilaian dilakukan dengan menggunakan lembar penilaian capaian perkembangan kognitif berupa ceklis capaian perkembangan yang disusun bersadarkan skala penilaian Belum Berkembang / 
Efektor, Volume 8 Issue 1, 2021, Pages 9 - 20

Veny Iswantiningtyas

$\mathrm{BB}=1$, Mulai Berkembang / $\mathrm{MB}=2$, Berkembang Sesuai Harapan / $\mathrm{BSH}=3$, Berkembang sangat baik / $\mathrm{BSB}=4$. Skala penilaian sebagai berikut :

Tabel 2. Kriteria penilaian capaian perkembangan anak

\begin{tabular}{cccc}
\hline BB & MB & BSH & BSB \\
\hline $\begin{array}{c}\text { Anak } \\
\text { menjawab/melakukan } \\
\text { dengan } \\
\text { bimbingan/dicontohkan }\end{array}$ & $\begin{array}{c}\text { Anak } \\
\text { menjawab/melakukan } \\
\text { harus dibantu/ } \\
\text { diingatkan }\end{array}$ & $\begin{array}{c}\text { Anak } \\
\text { denjawab/melakukan mandiri tanpa } \\
\text { dibantu }\end{array}$ & $\begin{array}{c}\text { menjawab/melakukan } \\
\text { dengan mandiri dan } \\
\text { dapat membantu } \\
\text { temannya }\end{array}$ \\
\hline
\end{tabular}

\section{HASIL DAN PEMBAHASAN}

Adanya pandemi covid-19 berdampak adanya perubahan di sistem pendidikan, aktivitas belajar mengajar sebelumnya dilakukan di sekolah saat ini berubah menjadi belajar di rumah menggunakan daring dan luring. Menurut (Kahfi, 2021) belajar daring memanfaatkan teknologi digital misalnya zoom, video converence, google classroom, serta yang lainnya. Selain itu, untuk memantau kegiatan belajar di rumah guru memberikan tugas dan melakukan pendampingan menggunakan whatsapp group. Lebih lanjut guru melakukan koordinasi bersama orang tua memakai video call serta foto aktivitas anak belajar dirumah, hal tersebut dilakukan untuk menunjukan membuktikan bahwa telah terjadi interaksi antara guru serta orang tua. Sedangkan belajar luring (Suhendro, 2020) pembelajaran luar jaringan (luring) suatu bentuk pembelajaran yang didalamnya terdapat sejumah metode misalnya kunjungan ke rumah, penggunaan materi, lembar kerja anak, alat peraga, serta berbagai media yang ada di sekitar lingkungan rumah yang sudah dipersiapakan guru.

Belajar di rumah secara daring maupun luring merupakan suatu pilihan yang tidak dapat dihindari, sehingga akan memicu terjadinya permasalah dalam pelaksaannya baik di kota maupun di desa. Harahap et al (2021) mengungkapkan fakta berbagai problematika pembelajaran daring yaitu : 1) sarana dan prasaran, 2) Kurangnya wawasan orang tua tentang pembelajaran bagi anak, 3) ketidaksiapan guru, orang tua dilihat dari waktu dan media pembelajaran, 3) anak usia dini memiliki fokus dan minat yang terbatas saat belajar, 4) Guru memiliki kendala apabila memberikan penilaian tugas yang diberikan ke anak. Pembelajaran luring problematikanya terbagi menjadi 2 yaitu : 1) Kunjungan ke rumah mempunyai permasalahan pada pembagian waktu pada setiap peserta didik serta membutuhkan biaya perjalan dan kendaraan untuk melakukan kunjungan ke rumah, 2) pelaksanaan pembelajaran luring dengan shift membutuhkan sarana protocol kesehatan bagi seluruh wilayah di Indonesia terutaman di daerah tertinggal, 3) Penerapan social distancing yang sulit diterapkan pada anak usia dini dengan fasilitas yang sangat minim karena anak usia dini merupakan anak yang aktif.

Pramana, (2020) mengungkapkan terdapat langkah-langkah yang perlu dilakukan untuk menghadapi proses pembelajaran dimasa pandemi covid-19 sebagai berikut : 1) Pemerintah, selama masa pandemi covid-19 pemerintah menghimbau agar guru PAUD tidak memberikan tugas beraneka ragam, selain itu hendaknya anak diberi keleluasaan bermain di rumah dibawah pengawasan serta bimbingan dari orang tuanya. Lebih lanjut, Dinas Pendidikan setempat harus berperan aktif untuk memberikan dukungan kepada guru dan orang tua murid. Mengambil berbagai langkah inovatif untuk memberikan solusi atas permasalahan yang terjadi dan mempertimbangkan suatu cara yang lebih baik lagi, guna memberikan pendidikan selama masa pandemi ini belum berakhir. 2) Institusi guru. Guru, anak dan orang tua harus dapat memanfaatkan teknologi informasi untuk belajar mengajar. Guru harus 


\section{Efektor, Volume 8 Issue 1, 2021, Pages 9 - 20}

Veny Iswantiningtyas

merancang kegiatan pembelajaran jarak jauh yang menyenangkan bagi anak sesuai kurikulum pendidikan dengan menggunakan teknologi. 3) Orang tua, diharapkan dapat membimbing dan mendampingi anaknya belajar di rumah, selain itu orang tua dapat mengantikan peran guru untuk mengajar dan membuat laporan perkembangan belajar. Lebih lanjut orang tua dan guru perlu mengkomunikasikan tentang berbagai kendala pelaksanaan pembelajaran agar diperoleh pemecahannya.

Salah satu tujuan belajar yang untuk anak berusia dini ialah mentimulasi perkembangan kognitifnya, supaya anak dapat menempatkan diri dilingkungannya dan mempunyai kesiapan untuk memasuki ke tahap perkembangan selanjutnya. Perkembangan kognitif anak berusia dini mencakup: 1) latihan memecahkan kesulitan, 2) berpikir rasional, 3) berpikir simbolik. (Permendikbud, No.137 tahun 2014). Faktor yang berpengaruh terhadap perkembangan kognitif anak adalah lingkungan, yang didalamnya terdapat lingkungan sekolah. Dimasa pandemi ini, hampir seluruh sekolah melakukan kegiatan belajar mengajar menggunakan sistem daring sehingga sedikit banyak akan dapat mempengaruhi capaian perkembangan kognitif anak. Berikut ini capaian perkembangan kognitif anak.

Tabel 3. Hasil Analisis Capaian belajar dan memecahkan masalah

\begin{tabular}{llllll}
\hline Nilai_A & $\begin{array}{l}\text { Sum of } \\
\text { Squares }\end{array}$ & df & $\begin{array}{l}\text { Mean } \\
\text { Square }\end{array}$ & F & Sig \\
\hline Between Groups & 1.226 & 2 & .613 & 1.670 & .194 \\
Within Groups & 33.032 & 90 & .367 & & \\
Total & 34.258 & 92 & & & \\
\hline
\end{tabular}

Berdasarkan tabel hasil analisis varians (ANOVA) di atas menunjukkan bahwa dengan menggunakan statistik uji $F$ diperoleh nilai Sig 0,194. Karena nilai Sig lebih besar dari alpha yang telah ditetapkan sebesar 0,05 maka keputusan yang diambil adalah menerima $\mathrm{H}_{0}$ dan menerima $\mathrm{H}_{1}$. Dengan demikian dapat disimpulkan bahwa semua pertanyaan pada aspek belajar dan memecahkan masalah mempunyai pengaruh yang sama. Sehingga dapat diketahui bahwa capaian belajar dan memecahkan masalah anak selama belajar di rumah tercapai. Belajar untuk memecahkan masalah adalah kemampuan yang patut dimiliki oleh anak, sebab didalam kehidupannya sehari-hari ia akan dipertemukan pada beragam permasalahan yang memerlukan kemampuan untuk memecahkan masalah tersebut. Syaodih et al (2018) mengungkapkan bahwa kemampuan memecahkan masalah pada seorang anak harus dikembangkan semenjak dini, hal tersebut dilakukan karena kemampuan memecahkan masalah berhubungan dengan cara seorang anak mengembangkan kemampuan kognitifnya. Lebih lanjut, Syaodih et al (2018) juga menjelaskan bahwa guru memiliki kontribusi untuk mengembangakan kemampuan memecahkan masalah pada anak, guru menghadapkan masalah dan mendiskusikan cara memecahkan masalah bersama anak, sehingga anak mengerti pentingnya berbagai cara pemecahan masalah. Menurut Wortham (2006) mengemukakan bahwa kemampuan memecahkan masalah pada anak usia dini terdiri dari: keterampilan mengobservasi, menggolongkan, menyamakan, menghitung, meringkas, menggunakan petunjuk. Lebih lanjut Lestariningrum \& Wijaya, (2020) untuk menghadapi abad ke-21 perlu membekali anak dengan pengetahuan umum dan kemampuan memecahkan masalah yang kan membuat anak sukses pada kehidupannya nanti.

Tabel 4. Hasil Analisis Capaian berpikir logis 
Efektor, Volume 8 Issue 1, 2021, Pages 9 - 20

Veny Iswantiningtyas

\begin{tabular}{llllll}
\hline Nilai_B & $\begin{array}{l}\text { Sum of } \\
\text { Squares }\end{array}$ & df & $\begin{array}{l}\text { Mean } \\
\text { Square }\end{array}$ & F & Sig \\
\hline Between Groups & .452 & 2 & .226 & .450 & .639 \\
Within Groups & 45.161 & 90 & .502 & & \\
Total & 45.613 & 92 & & & \\
\hline
\end{tabular}

Berdasarkan tabel hasil analisis varians (ANOVA) di atas menunjukkan bahwa dengan menggunakan statistik uji $F$ diperoleh nilai Sig 0,639. Karena nilai Sig lebih besar dari alpha yang telah ditetapkan sebesar 0,05 maka keputusan yang diambil adalah menerima $\mathrm{H}_{0}$ dan menerima $\mathrm{H}_{1}$. Dengan demikian dapat disimpulkan bahwa semua pertanyaan pada aspek bepikir logis mempunyai pengaruh yang sama. Sehingga dapat diketahui bahwa capaian berpikir logis anak selama belajar di rumah tercapai. Bepikir logis merupakan bagian dari perkembangan kognitif yang searah dengan tujuan pendidikan bagi anak usia dini yaitu supaya anak dapat berpikir secara logis di dalam kehidupan seharihari. Menurut Kurniasari et al (2018) mengemukakan bahwa bahwa dalam menjalani kehidupan seharihari diperlukan kemampuan berpikir logis, karena beripikir logis merupakan pendukung keberhasilan tindakan dalam mengambil keputusan. Kemampuan tersebut tentu dibutuhkan oleh setiap orang dalam menjalankan kehidupannya. Sejalan dengan penelitian yang dilakukan oleh Hewi \& Asnawati (2020) cara yang digunakan guru untuk mengembangkan kemampuan berpikir logis anak di masa pandemi covid-19 adalah guru melakukan dua tugas utama sebagai perencana serta memberikan penilai terhadap perkembangan anak, sedangkan orang tua berperan sebagai pelaksana pembelajaran menggunakan metode bercakap-cakap, tanya jawab, keteladanan yakni mengajak anak memahami kenapa harus sekolah dirumah, kenapa harus menggunakan masker apabila keluar rumah, mengapa tidak boleh bermain di luar rumah. Penerapan strategi ini dapat membuat anak mengetahui sebab akibat sebagai indikator capaian perkembangan kognitif lingkup berpikir logis.

Tabel 5. Hasil Analisis Capaian berpikir simbolik

\begin{tabular}{llllll}
\hline Nilai_C & $\begin{array}{l}\text { Sum of } \\
\text { Squares }\end{array}$ & df & $\begin{array}{l}\text { Mean } \\
\text { Square }\end{array}$ & F & Sig \\
\hline Between Groups & 6.086 & 2 & 3.043 & 4.051 & .021 \\
Within Groups & 67.613 & 90 & .751 & & \\
Total & 73.699 & 92 & & & \\
\hline
\end{tabular}

Berdasarkan tabel hasil analisis varians (ANOVA) di atas menunjukkan bahwa dengan menggunakan statistik uji $F$ diperoleh nilai Sig 0,021. Karena nilai Sig lebih kecil dari alpha yang telah ditetapkan sebesar 0,05 maka keputusan yang diambil adalah menolak $\mathrm{H}_{0}$ dan menerima $\mathrm{H}_{1}$. Dengan demikian dapat disimpulkan bahwa semua pertanyaan pada aspek bepikir Isimbolik mempunyai pengaruh yang sama. Sehingga dapat diketahui bahwa capaian berpikir simbolik anak selama belajar di rumah tercapai. Berpikir simbolik merupakan salah satu unsur perkembangan kognitif yang harus dimiliki anak, menurut Piaget kemampuan berpikir simbolik adalah kemampuan untuk berpikir tentang objek dan peristiwa, walaupun objek dan peristiswa tersebut tidak hadir secara nyata di hadapan anak. Kemampuan berpikir simbolik anak terjadi pada rentang usia 2-7 tahun masa ini disebut tahapan praoprasional, Santrock (2008). Menurut Mingrui et al (2014) berpikir simbolik tergolong tahap mengetahui konsep, konsep tersebut dipelajari supaya anak mengetahui suatu objek akan tetapi tidak tergantung pada sesuatu yang nyata, konsep ini sangat berarti untuk dipelajari anak karena dapat menjadi bekal 


\section{Efektor, Volume 8 Issue 1, 2021, Pages 9 - 20}

Veny Iswantiningtyas

pada kehidupan anak di dunia pendidikan serta kehidupannya. Selain itu Zahwa et al (2018) menyampaikan bermain memerankan penjual dan pembeli berpura-pura membawa uang mainan terbukti mampu membuat anak dapat menumbuhkan daya fikir serta majinasinya, sehingga anak tersebut akan mampu menarik pengalamannya kedalam bermain simbolik. Keterampilan berpikir simbolik anak akan tampak ketika ia mampu menggunakan beragam simbol gambar dan angka. Setiawan et al (2020) melalui kegiatan story telling yang dilakukan secara daring yaitu anak diajak oleh orang tuanya untuk menyimak video dan memahami materinya, selanjutnya orang tua mengajak anak beriskusi dan mendemonstrasikannya. Dari hasil kegiatan yang dilakukan anak dan ortu selama pandemi ini kemampuan berpikir logis meningkat yaitu anak dapat menyebutkan beragam benda sesuai dengan fungsinya.

Berdasarkan uraian diatas dapat ketahui bahwa selama anak belajar di rumah perkembangan kognitif anak tetap tercapai. Tercapainya perkembangan kognitif anak atas kerjasama berbagai pihak yaitu : guru yang dapat menyesuaikan diri untuk menggunakan teknologi informasi ketika proses belajar mengajar, peserta didik yang selalu semangat belajar di rumah, orang tua yang tetap setia menemani anaknya belajar di rumah. Sejalan dengan hasil penelitian Nur Hayati (2007) sikap orang tua yang dapat menunjang perkembangan kognitif anak yaitu: 1) menghargai pendapat anak serta mendorongnya untuk mengungkapkannya, 2) memberikan kesempatan kepada anak untuk berpikir, merenung serta berhayal, 3) mengizinkan anak mengambil keputusan sendiri, 4) menstimulasi anak banyak bertanya, 5) meyakinkan anak bahwa orang tua menghargai apa yang ingin di coba, dilakukan dan dihasilkan, 6) mendorong dan menunjang kegiatan yang dilakukan anak, 7) menikmati keberadaaanya bersama anak, 8) memberikan penghargaan kepada anak dengan sunguh-sunguh, 9) mendorong anak untuk bekerja mandiri,10) menjalin hubungan kerja sama yang baik dengan anak.

Sistem pembelajaran TK Kusuma Mulia Sidomulyo I Puncu Kediri di masa pandemi covid-19 berbeda dari sebelum adanya pandemi yaitu penyusunan rencana pembelajaran mengalami perubahan. Seperti pada tahun sebelumnya, sebelum tahun ajaran baru dimulai terlebih dahulu Kepala sekolah bersama seluruh guru TK Kusuma Mulia Sidomulyo I Puncu Kediri melakukan kegiatan rapat kerja tahunan untuk menyusun program semester, RPPM dan RPPH yang akan digunakan. Selaras dengan hasil penelitian yang telah dilakukan oleh Shofa (2020) agar kualitas pembelajaran dan perkembangan anak tetap tercapai dengan baik di masa pandemi covid-19 diperlukan berbagai inovasi pembelajaran yaitu : 1) inovasi dalam menyusun perencanaan pembelajaran berupa promes, RPPM, RPPH. 2) pembelajaran daring menggunakan whatsapp group dan google classroom. 3) home visit yang dilakukan secara terjadwal untuk memantau perkembangan anak selama belajar di rumah. 4) pembelajaran luring menggunakan sistem rolling. 5) evaluasi perkembangan anak menggunakan google form yang dilakukan atas kerjasama antara guru dan orang tua.

Program semester merupan suatu perencanaan pembelajaran yang akan dilakukan dalam waktu satu semester yang berisi kompetensi dasar, daftar tema satu semester dan alokasi waktu setiap tema. Tema pembelajaran dapat dikembangkan menjadi sub tema dan sub tema dapat dikembangkan menjadi sub-sub tema, Wayuni dalam Shofa (2020). Program semester di TK Kusuma Mulia Sidomulyo I Puncu Kediri di masa pandemi covid-19 secara signifikan tidak mengalami perubahan, dimana tema tema pembelajaran yang di sampaikan masih sama seperti tema pembelajaran diluar pandemi covid19.

Rencana pelaksanaan pembelajaran mingguan (RPPM) merupakan susunan pembelajaran yang akan dilakukan selama satu minggu. RPPM berisi : 1) identitas program layanan, 2) kompentensi 


\section{Efektor, Volume 8 Issue 1, 2021, Pages 9 - 20}

Veny Iswantiningtyas

dasar yang dipilih, 3) materi pelajaran, 4) rencana kegiatan. Format RPPM TK Kusuma Mulia Sidomulyo I Puncu Kediri di masa pandemi covid-19 mengalami perubahan, akan tetapi pada bagian materi dan rencana kegiatan perubahan dari model pembelajaran kelompok ke stimulasi berbagai aspek perkembangan anak.

Rencana pelaksanaan pembelajaran harian (RPPH) merupakan suatu pedoman untuk melakukan kegiatan belajar seraya bermain dalam satu hari. Format RPPH tidak baku, akan tetapi mencantumkan berbagai kompenen yang ditetapkan. Komponen RPPH terdiri dari : 1) identitas program, 2) materi, 3) alat dan bahan, 4) kegiatan pembuka, 5) kegiatan inti, 6) kegiatan penutup, 7) rencana penilaian. RPPH TK Kusuma Mulia Sidomulyo I Puncu Kediri dibuat guru setiap harinya. Dalam masa pandemi covid-19 terdapat perubahan format RPPH akan tetapi tidak mengurangi komponen dari RPPH. Penyusunan RPPH yang biasanya disusun setiap hari dimasa pandemi covid-19 guru menyusun RPPH untuk 1 minggu sekalian. Hal tersebut dilakukan untuk menyingkat waktu perencanaan yang lebih maksimal terkait media pembelajaran yang digunakan, pembuatan video pembelajaran dan lain sebagainya. Media pembelajaran dalam hal ini, guru menyiapkannya untuk 1 minggu di hari jumat. Pada hari jumat tersebut orang tua wali murid mengambil media tersebut di sekolah untuk diginakan dalam pembelajaran minggu berikutnya.

Salah satu aplikasi social media yang akrab di semua lapisan masyarakat adalah aplikasi whatsapp. Pada aplikasi yang terdapat di whatshapp memiliki beragam fitur diantaranya dapat mengirimkan pesan, voice note, video, foto, dokumen dan terdapat group yang mampu menampung 100 orang lebih anggotanya. Lengkapnya fitur dan mudahnya cara mengoperasikannya membuat masyarakat akrab, maka tak heran apabila whatsapp merupakan suatu media yang cukup populer saat melakukan pembelajaran daring pada semua jenjang pendidikan termasuk di TK Kusuma Mulia Sidomulyo I Puncu Kediri. Guru di TK Kusuma Mulia Sidomulyo I Puncu Kediri menjelaskan bahwa pembelajaran daring menggunakan media whatsapp untuk berkomunikasi antara guru dan orang tua murid dengan cara terlebih dahulu guru membagikan materi dan kegiatan pembelajaran berupa pesan, foto, voice note di whatsapp grup, kemudian orang tua mendampingi anaknya melakukan kegiatan dirumah selanjutnya orang tua melaporkannya di whatsapp grup tersebut. Penggunaan whatsapp grup dalam pembelajaran tersebut sejalan dengan hasil penelitian Hutami \& Nugraheni (2020) menjelaskan bahwa agar peserta didik tetap bersemangat untuk melakukan pembelajaran daring di masa pandemi covid-19 guru menggunakan suatu strategi yakni menggunakan media whatsapp. Selain itu, Utanto \& Dewanti (2020) mengemukakan bahwa pemanfaatan teknologi informasi dan komunikasi memiliki peran penting karena kunci keberhasilan dari pembelajaran online pada masa pandemi covid-19 adalah penguasaan teknologi, beberapa media yang menjadi pilihanan dalam proses pembelajaran anak usia dini ialah whatshap group, zoom serta media lainnya yang dapat menunjang berlangsungnya kegiatan pembelajaran.

Sejak pandemi covid-19 tidak diperbolehkan untuk melakukan pembelajaran tatap muka, maka pihak TK Kusuma Mulia Sidomulyo I Puncu Kediri menggunakan metode pembelajaran home visit atau kunjuangn kerumah. Keputusan menggunakan metode tersebut telah mendapatkan persetujuan wali murid, agar anaknya mendapatkan pembelajaran secara langsung dari gurunya. Home visit dilakukan dengan cara kunjungan guru ke rumah peserta didik dan mengumpulkannya peserta didik yang tempat tinggalnya berdekatan masimal 5 anak. Jadwal pembelajaran di setiap kelas home visit satu kali satu minggu dengan waktu pembelajaran dimulai pukul 07.30 sampai dengan 09.00 wib. Sebelum kegiatan home visit dilakukan, terlebih dahulu guru memberitahukan kepada orang tua tentang jadwal home visit 


\section{Efektor, Volume 8 Issue 1, 2021, Pages 9 - 20}

Veny Iswantiningtyas

melalui whatsapp group, selanjutnya orang tua memberikan respon jadwal tersebut. Apabila ada orang tua tidak dapat mengikuti jadwal yang telah dibuat, orang tua diperbolehkan untuk menukarkannya. Nirmala \& Annuar (2020) mengemukakan kegiatan home visit yang dilakukan guru merupakan sarana untuk menginformasikan kepada orang tua terkait berbagai usaha yang peru dilakukan oleh orang tua utnuk mendukung pengembangan bakat, minat dan potensi anak secara utuh dan menyeluruh selama belajar dirumah. Orang tua yang tidak memiliki pengetahuan tentang pekembangan anak membutuhkan seseorang atau lembaga yang dapat membantunya untuk memberikan stimulasi serta memamtau tahapan perkembangan anak. Sejalan dengan penelitain yang dilakukan oleh Sudrajat et al 2020) bahwa untuk mengoptimalkan kegiatan pembelajaran selama masa pandemi covid-19 diperlukan kegiatan home visit, kegiatan tersebut sangatlah penting karena salah satu cara agar aspek perkembangan anak dapat dipantau oleh guru.

Evaluasi merupakan suatu kegiatan yang dilakukan pendidikan dengan cara mengumpulkan beragai informasi dalam menentukan kuantitas dan kualitas perkembangan anak, Farantika \& Indrawati (2021). Selama anak belajar di rumah evaluasi yang di lakukan bukan melihat hasil akhir dari apa yang telah dilakukan anak, akan tetapi lebih melihat proses bagaimana anak melakukan kegiatan tersebut. Evaluasi yang dilakukan guru di TK Kusuma Mulia Sidomulyo I Puncu Kediri menggunakan model cheklist. Guru mengecek aktivitas anak di rumah menggunakan whatsapp grup dan home visit. Biasanya guru akan menyapa anak dengan bercakap-cakap, bertanya kabar, menanyakan apa yang dilakukan anak. Proses melakukan evaluasi dapat dilihat dari hasil kiriman video, foto, voicnote orang tua yang dikirimkan melalui whatsapp group. Pada tahap evaluasi pembelajaran home visit bentuk cheklist diberikaan seminggu sekali di awal kunjungan, guru meminta kepada orang tua untuk mencheklist kegiatan apa saja yang telah dilakukan dan yang belum dilakukan. Pada saat visit kedua, guru melihat kembali kegiatan yang sudah dilakukan dan belum dilakukan. Kemudian guru melakukan wawancara dengan orang tua untuk mencari informasi lebih dalam mengenai kegiatan yang sudah dilakukan. Selain itu, guru juga menanyakan kepada orang tua terkait kendala apa saja yang dihadapi selama proses pembelajaran di rumah.

\section{SIMPULAN}

Keputusan penelitian memperlihatkan perkembangan kognitif anak selama belajar dirumah tercapai. Selama anak belajar dirumah anak dibimbing orang tua serta guru menggunakan metode belajar daring dan luring. Ketika anak belajar dirumah anak mendapatkan pengalaman belajar yang bermakna dan anak tidak dibebani oleh ketuntasan capaian kurikulum. Penelitian ini memiliki keterbatasan diantaranya subyek penelitian yang digunakan sedikit yaitu 31 anak, sehingga untuk hasilnya kurang digeneralisasikan. Penelitian hanya bertujuan melihat capaian perkembangan kognitif anak tidak menggali capaian pekembangan yang lain pada anak. Oleh sebab itu, hendaknya pada penelitian berikutnya disarankan untuk memasukkan subyek yang lebih banyak dan melibatkan aspek perkembangan yang lain.

\section{DAFTAR RUJUKAN}

Astuti, I. Y., \& Harun, H. (2020). Tantangan Guru dan Orang Tua dalam Kegiatan Belajar Dari Rumah Anak Usia Dini pada Masa Pandemi Covid-19. Jurnal Obsesi : Jurnal Pendidikan Anak Usia Dini, 5(2), 1454-1463. https://doi.org/10.31004/obsesi.v5i2.808

Farantika, D., \& Indrawati, D. (2021). Sistem Pembelajaran Dari Rumah Melalui Model Daring TK Al Muhajirin Kota Malang Saat Pandemi Covid-19. Jurnal Pendidikan : Riset Dan Konseptual, 5(1), 128. https://doi.org/10.28926/riset_konseptual.v5i1.326 
Harahap, S. A., Dimyati, D., \& Purwanta, E. (2021). Problematika Pembelajaran Daring dan Luring Anak Usia Dini bagi Guru dan Orang tua di Masa Pandemi Covid 19. Jurnal Obsesi : Jurnal Pendidikan Anak Usia Dini, 5(2), 1825-1836. https://doi.org/10.31004/obsesi.v5i2.1013

Hewi, L., \& Asnawati, L. (2020). Strategi Pendidik Anak Usia Dini Era Covid-19 dalam Menumbuhkan Kemampuan Berfikir Logis. Jurnal Obsesi: Jurnal Pendidikan Anak Usia Dini, 5(1), 158. https://doi.org/10.31004/obsesi.v5i1.530

Hutami, M. S., \& Nugraheni, A. S. (2020). Metode Pembelajaran Melalui Whatsapp Group Sebagai Antisipasi Penyebaran Covid-19 pada PAUD di TK ABA Kleco Kotagede. Paudia: Jurnal Penelitian Dalam Bidang Pendidikan Anak Usia Dini, 9(1), 126-130.

Jamaris, Martini. 2013. Orientasi Baru dalam Psikologi Pendidikan. Bogor : Ghalia Indonesia

Kahfi, A. (2021). Dampak pembelajaran daring di masa pandemi covid 19 terhadap perkembangan kognitif anak. Jurnal Pemikiran Dan Pendidikan Dasar Islam, 4(1), 14-23. https://staibinamadani.e-journal.id/jurdir/article/view/219

Kurniasari, I., Sasmiati, \& Haenilah, E. Y. (2018). Penggunaan Media Alam Sekitar dan Kemampuan Berfikir Logis Anak Usia Dini. Jurnal Pendidikan Anak, 4(1), 1-9.

Lestariningrum, A., \& Wijaya, I. P. (2020). Penerapan Bermain Loose Parts untuk Kemampuan Memecahkan Masalah Sederhana Anak Usia 4-5 Tahun. Pedagogika, 11(2), 104-115. https://doi.org/10.37411/pedagogika.v11i2.174

Iswantiningtyas, V. (2020) Strategi Pendidik Anak Untuk Mengembangkan Kemampuan Memecahkan Masalah Selama Belajar di Rumah. Prosiding Seminar Nasional Pendidikan Anak Usia Dini, 1(1), 77-82.

Mutmainnah. (2020). Starategi pendidik Anak Usia Dini Era Covid-19 dalam Menumbuhkan Kemampuan Critical Thinking. PAUD Lectura: Jurnal Pendidikan Anak Usia Dini, Vol 4 No 1, Oktober 2020. 4(1), 87-96. https://doi.org/10.31849/paud-lectura.v

Nirmala, B., \& Annuar, H. (2020). Home Visit: Strategi PAUD dari Rumah bagi Guru di Daerah 3T pada Masa Pandemi Covid-19. Jurnal Obsesi : Jurnal Pendidikan Anak Usia Dini, 5(2), 1052-1062. https://doi.org/10.31004/obsesi.v5i2.716

Nur Hayati. (2007). secara optimal anak. menempatkan posisi pendidik sebagai pendamping, pembimbing serta fasilitator bagi Pada masa usia dini anak mengalami masa keemasan. 23-26.

Patmonodewo, Soemiarti. 2008. Pendidikan Anak Prasekolah. Jakarta : PT Rineka Cipta

Permendikbud. (2014). Standar Nasional Penilian PAUD No. 137. Menteri Kesehatan Republik Indonesia Peraturan Menteri Kesehatan Republik Indonesia, Nomor 65(879), 2004-2006.

Pramana, C. (2020). Pembelajaran Pendidikan Anak Usia Dini (PAUD) Dimasa Pandemi Covid-19. Indonesian Journal of Early Childhood: Jurnal Dunia Anak Usia Dini, 2(2), 116-124. https://doi.org/10.35473/ijec.v2i2.557

Setiawan, E., Dewi, M. S., Ummah, S., \& Malang, U. I. (2020). STORY TELLING MELALUI DARING DOI : A . PENDAHULUAN National Association for the Education Young Children ( NAEYC ) mendefinisikan anak usia dini sebagai anak yang berada pada usia 0 sampai dengan 8 tahun (. Jurnal Perkembangan Dan Pendidikan Anak Usia Dini, 2, 163-173.

Setyaningrum, S. R., Triyanti, T., \& Indrawani, Y. M. (2014). Pembelajaran di Pendidikan Anak Usia Dini dengan Perkembangan Kognitif pada Anak. Kesmas: National Public Health Journal, 243. https://doi.org/10.21109/kesmas.v0i0.375 
Shofa, M. F. (2020). Inovasi pembelajaran pada pendidikan anak usia dini di masa pandemi covid-19. Buana Gender, 5(2), 85-96.

Sudrajat, C. J., Agustin, M., Kurniawati, L., \& Karsa, D. (2020). Strategi Kepala TK dalam Meningkatkan Mutu Pendidikan pada Masa Pandemi Covid 19. Jurnal Obsesi : Jurnal Pendidikan Anak Usia Dini, 5(1), 508. https://doi.org/10.31004/obsesi.v5i1.582

Suhendro, E. (2020). Strategi Pembelajaran Pendidikan Anak Usia Dini di. Golden Age: Jurnal IImiah Tumbuh Kembang Anak Usia Dini, 5(September), 133-140.

Suwardi dan Daryanto. 2017. Manajemen Peserta Didik. Yogyakarta : Gaya Media

Syaodih, E., Setiasih, O., Romadona, N. U. R. F., \& Handayani, H. (2018). Pengembangan Kemampuan Pemecahan Masalah Anak Usia Dini dalam Pembelajaran Proyek di Taman KanakKanak. Jurnal Pendidikan Anak, 12(1), 29-36.

Tatminingsih, S. (2019). Alternatif Stimulasi Kemampuan Kognitif melalui Penerapan Model Pembelajaran Berbasis Permainan Komprehensif. Jurnal Obsesi : Jurnal Pendidikan Anak Usia Dini, 3(1), 183. https://doi.org/10.31004/obsesi.v3i1.130

Utanto, Y., \& Dewanti, S. S. (2020). Analisa Pemanfaatan Teknologi Informasi dan Komunikasi Sebagai Media Pembelajaran Anak Usia Dini di Masa Pandemi Covid -19.

Wardani, A., \& Ayriza, Y. (2020). Analisis Kendala Orang Tua dalam Mendampingi Anak Belajar di Rumah Pada Masa Pandemi Covid-19. Jurnal Obsesi : Jurnal Pendidikan Anak Usia Dini, 5(1), 772. https://doi.org/10.31004/obsesi.v5i1.705

Wulandari, H., \& Purwanta, E. (2020). Pencapaian Perkembangan Anak Usia Dini di Taman Kanakkanak selama Pembelajaran Daring di Masa Pandemi Covid-19. Jurnal Obsesi : Jurnal Pendidikan Anak Usia Dini, 5(1), 452. https://doi.org/10.31004/obsesi.v5i1.626

Zahwa, S. A., Nisa', T. F. F., \& Fajar, Y. W. (2018). Pengaruh Metode Bermain Peran Makro Terhadap Kemampuan Berpikir Simbolik Anak Kelompok B. Jurnal PG-PAUD Trunojoyo : Jurnal Pendidikan Dan Pembelajaran Anak Usia Dini, 5(1), 30. https://doi.org/10.21107/jpgpaud.v5i1.3848 